\title{
PENERAPAN MODEL PEMBELAJARAN KOOPERATIF TIPE TAI BERBANTUAN BUKU SAKU PADA MATERI REDOKS UNTUK MENINGKATKAN KEMANDIRIAN BELAJAR DAN PRESTASI BELAJAR SISWA KELAS X MIA 5 SMA NEGERI 2 BOYOLALI
}

\author{
Lasni Julita Sitanggang ${ }^{*}$, Mohammad Masykuri, dan Ashadi \\ Program Studi Pendidikan Kimia, FKIP, Universitas Sebelas Maret, Surakarta, Indonesia \\ *keperluan korespondensi, email: lasni.sitanggang@gmail.com
}

\begin{abstract}
ABSTRAK
Penelitian ini bertujuan untuk meningkatkan kemandirian belajar dan prestasi belajar siswa kelas X MIA 5 SMA Negeri 2 Boyolali tahun pelajaran 2016/2017 melalui penerapan model pembelajaran cooperative learning tipe Team Assisted Individualization (TAI) pada materi redoks. Penelitian ini merupakan penelitian tindakan kelas. Teknik analisis data yang digunakan berupa analisis deskriptif kualitatif. Hasil dari penelitian yang telah dilakukan menunjukkan bahwa penerapan model pembelajaran TAI pada materi redoks dapat meningkatkan kemandirian belajar dan prestasi belajar siswa kelas X MIA 5 SMA Negeri 2 Boyolali. Hasil analisis kemandirian belajar siswa pada siklus I sebesar $81,6 \%$ dan meningkat pada siklus II menjadi $89,5 \%$. Hasil prestasi belajar siswa pada siklus I sebesar $55,3 \%$ dan pada siklus II meningkat menjadi $73,7 \%$. Hasil prestasi belajar aspek sikap sebesar $89,47 \%$. Hasil prestasi belajar siswa pada aspek keterampilan sebesar $100 \%$.
\end{abstract}

Kata kunci: penelitian tindakan kelas, Team Assisted Individualization, kemandirian belajar, prestasi belajar

\section{PENDAHULUAN}

Upaya peningkatan kualitas pendidikan di Indonesia terus dilakukan, salah satunya dengan pembaharuan kurikulum. Kurikulum di Indonesia terus diperbaharui sesuai dengan kebutuhan zaman, hingga saat ini dilakukan penerapan kurikulum 2013.Kurikulum 2013 menekankan keseimbangan antara hardskill dan softskill siswa. Pembelajaran pada kurikulum 2013 menggunakan pendekatan saintifik yang mendorong siswa untuk aktif dan kreatif. Dalam proses pembelajaran, guru berperan dalam mengelola kelas agar siswa dapat terlibat aktif dan kreatif. Pembelajaran yang aktif dan kreatif dapat diciptakan melalui model pembelajaran yang inovatif. Pembelajaran kimia terkesan sulit bagi siswa dikarenakan ilmu kimia yang bersifat abstrak dan berkaitan dengan ilmu pengetahuan lainnya [1]. Pembelajaran kimia perlu dilakukan secara efektif agar siswa dapat memahami pelajaran dengan baik. Pembelajaran kimia masih berlangsung secara konvensional, yaitu guru lebih aktif daripada siswa karena guru menjelaskan materi kepada siswa dan siswa hanya mendengarkan penjelasan dari guru saja. Metode konvensional tersebut tidak sesuai dengan kurikulum 2013 karena siswa tidak terlibat aktif dan pembelajaran tersebut tidak merangsang kreativitas siswa. Metode konvensional dalam pembelajaran kimia membuat siswa sulit memahami materi kimia karena siswa hanya mendengarkan penjelasan dari guru tanpa aktif terlibat dalam memahami materi. Hal ini terjadi pada siswa-siswi di kelas X MIA SMA Negeri 2 Boyolali.

SMA Negeri 2 Boyolali merupakan salah satu SMA di kabupaten Boyolali yang aksesnya cukup jauh dari perkotaan. Siswa-siswi SMA Negeri 2 
Boyolali berasal dari latar belakang dan tempat tinggal yang berbeda sehingga dapat dikatakan secara umum merupakan siswa-siswi heterogen. Pembelajaran kimia di kelas $X$ SMA Negeri 2 Boyolali merupakan metode konvensional dan diskusi. Metode konvensional dalam pembelajaran di SMA Negeri 2 Boyolali yaitu guru menjelaskan materi dengan rinci kemudian memberikan contoh soal yang dibahas bersama-sama. Pembelajaran terkadang dilakukan melalui diskusi kelompok, namun diskusi juga berlangsung kurang optimal karena hanya sebagian kecil siswa yang aktif dan guru tetap aktif memberikan penjelasan kepada siswa pada tugas-tugas kelompok. Hal ini mengindikasikan kurangnya kemandirian belajar siswa dalam memahami materi dan mengerjakan tugas-tugas belajarnya.

Materi redoks sebagai salah satu materi yang dipelajari di kelas $X$ semester genap pada kurikulum 2013 mencakup perkembangan konsep redoks hingga perhitungan bilangan redoks yang dijadikan dasar dalam tata nama senyawa. Dalam memahami materi redoks, siswa perlu memahami konsep redoks terlebih dahulu agar dapat menghitung bilangan redoks dalam suatu senyawa atau reaksi kimia. Siswa perlu latihan-latihan soal dalam perhitungan redoks sehingga perlu diterapkan suatu inovasi model pembelajaran yang dapat membuat siswa mandiri dalam memahami dan mengerjakan latihan-latihan soal redoks. Model pembelajaran yang dapat diterapkan untuk meningkatkan kemandirian belajar dan prestasi belajar siswa pada materi redoks adalah model pembelajaran kooperatif tipe Team Assisted Individualization (TAI).

Model pembelajaran kooperatif merupakan suatu model pembelajaran yang menerapkan belajar secara berkelompok, saling membantu dan mendorong satu sama lain untuk berhasil [2]. Model pembelajaran kooperatif dapat memicu siswa untuk berpikir lebih kompleks dan memecahkan masalah sehingga tujuan belajar dapat tercapai
[3]. Model pembelajaran kooperatif tipe TAl mengkombinasikan antara pembelajaran kooperatif dengan pengajaran individual [4]. Dalam penerapannya, siswa dituntut untuk mandiri dalam mengerjakan tugas-tugas belajar yang kemudian dilakukan secara kooperatif dengan teman sekelompoknya. Pada model pembelajaran kooperatif, terdapat seorang siswa yang berperan sebagai asisten kelompok. Asisten kelompok bertugas memimpin jalannya diskusi kelompok. Adanya asisten dalam kelompok dapat mengecek anggota kelompoknya yang masih belum paham terhadapmateri yang dipelajari sehingga pemahaman dalam kelompok tersebut dapat menjadi lebih merata [5]. Penerapan TAI dapat meningkatkan prestasi belajar siswa karena dalam penerapannya, terjadi interksi antar siswa dan reward yang mempengaruhi minat dan motivasi siswa dalam belajar [6]. Penerapan TAI dalam pembelajaran kimia juga dapat meningkatkan pemahaman siswa pada materi kimia, meningkatkan keaktifan siswa dalam diskusi kelompok, dan kepercyaan diri siswa untuk mengerjakan soal dan mempresentasikannya [7].

Model pembelajaran TAI yang dipadukan dengan media pembelajaran dapat mendukung proses pembelajaran. Media pembelajaran yang digunakan disesuiakan dengan sifat materi dan kebutuhan siswa [8]. Sesuai dengan tujuan dari penerapan model pembelajaran TAI, maka digunakan media belajar dalam bentuk buku saku yang berisi materi pembelajaran dan latihan soal dilengkapi langkah-langkah penyelesaian yang dapat digunakan siswa sebagai pegangan dalam menyelesaikan tugas-tugas belajar. Penggunaan media pembelajaran buku saku memberikan kepraktisan dalam penggunaannya sebagai sumber belajar mandiri [9]. Penerapan model pembelajaran kooperatif tipe TAl diharapkan dapat meningkatkan kemandirian belajar dan prestasi siswa pada materi pokok redoks. 


\section{METODE PENELITIAN}

Penelitian ini merupakan Penelitian Tindakan Kelas (PTK) yang terdiri dari dua siklus. Setiap siklusnya terdapat empat tahapan, yaitu perencanaan, pelaksanaan, observasi, dan refleksi. Subjek penelitian adalah siswa kelas $X$ MIA 5 SMA Negeri 2 Boyolali.

Data penelitian yang diperoleh berupa data kualitatif dan data kuantitatif. Data kualitatif merupakan data hasil wawancara, hasil observasi, angket sikap, dan angket kemandirian. Data kuantitatif merupakan data hasil penilaian prestasi belajar materi pokok redoks pada aspek kognitif dan keterampilan.

Teknik analisis data pada penelitian ini merupakan analisis deskriptif. Analisis data terdiri dari tiga tahap yaitu reduksi data (pengelolaan data), penyajian data (menyajikan data kedalam suatu bentuk tertentu sehingga datanya terlihat lebih utuh), dan triangulasi data atau pemeriksaan keabsahan data dengan memanfaatkan sesuatu yang lain diluar data tersebut sebagai pembanding data. Triangulasi data dilakukan jika terdapat perbedaan hasil analisis pada metode angket dan metode observasi.

\section{HASIL DAN PEMBAHASAN}

Penelitian tindakan kelas ini bertujuan untuk meningkatkan kemandirian belajar dan prestasi belajar siswa kelas X MIA SMA Negeri 2 Boyolali pada materi pokok redoks melalui penerapai model pembelajaran kooperatif tipe TAI berbantuan buku saku.Prestasi belajar siswa yang diukur terdiri dari aspek kognitif, aspek sikap, dan aspek pengetahuan.

Penelitian ini terdiri dari 2 siklus. Masing-masing siklus terdiri dari tahap perencanaan, tahap pelaksanaan tindakan, tahap pengamatan dan tahap refleksi. Pembelajaran dilakukan secara berkelompok dan tiap kelompok dipimpin oleh seorang asisten.

\section{Siklus I}

\section{a. Perencanaan}

Tahap perancanaan merupakan tahap persiapan sebelum dilakukan penelitian, yang dilakukan dengan menyusun silabus, Rencana Pelaksanaan Pembelajaran (RPP), buku saku, instrumen penilaian kemandirian dan instrumen penilaian prestasi belajar Siklus I terdiri dari 4 pertemuan (8jp), yaitu 3 pertemuan untuk penyampaian materi $(6 \times 45$ menit) dan 2 jp ( $2 \times 45$ menit) untuk evaluasi pada akhir siklus I.

\section{b. Pelaksanaan}

Pelaksanaan tindakan siklus I terdiri dari 4 kali pertemuan, dengan 23 kali pertemuan untuk penyampaian materi dan 1 pertemuan di akhir siklusi untuk evaluasi. Sub materi pada pertemuan pertama adalah perkembangan konsep reaksi redoks. Pertemuan diawali dengan penjelasan mengenai penerapan model pembelajaran TAI. Guru mengawali pelajaran dengan menyampaikan apersepsi sebelum menjelaskan materi secara umum. Setelah penyampaian materi, guru memberi kesempatan bagi siswa untuk bertanya. Guru lalu membagi siswa menjadi tujuh kelompok seperti yang telah ditentukan sebelumnya dengan asisten pada tiap kelompok. Setelah kelompok terbentuk, siswa diberi buku saku dan lembar kerja. Siswa kemudian mengerjakan soal-soal yang ada di lembar kerja secara individual. Guru kemudian memberi instruksi untuk mendiskusikan soal yang diberikan dengan kelompoknya dengan dipimpin oleh masing-masing asisten. Beberapa kelompok maju ke depan kelas untuk mempresentasikan hasil diskusi dan diikuti dengan konfirmasi dari guru. Setelah konfirmasi, guru bersama dengan siswa menarik kesimpulan dari hasil pembelajaran. Pembelajaran diakhiri dengan kuis mengenai materi yang telah dipelajari. Dari awal hingga akhir pembelajaran, observer melakukan penilaian observasi. 
Pertemuan kedua dan ketiga berlangsung sama seperti pertemuan pertama. Pada pertemuan kedua, sub materinya adalah bilangan oksidasi,dan pertemuan ketiga sub materinya adalah pengoksidasi, pereduksi, dan nama senyawa. Pada pertemuan keempat, dilakukan evaluasi pembelajaran dengan ujian tertulis pengisian angket kemandirian dan sikap.

\section{c. Pengamatan}

Hasil penilaian observasi dan analisis hasil tes pada siklus I dapat dibuat dalam beberapa kategori-kategori. Hasil penilaian sikap siswa digolongkan menjadi 3 kategori, yaitu Sangat Baik (SB), Baik (B), Cukup (C), dan Kurang (K). Hasil penilaian sikap disajikan dalam kategori tersebut seperti pada Gambar 1.

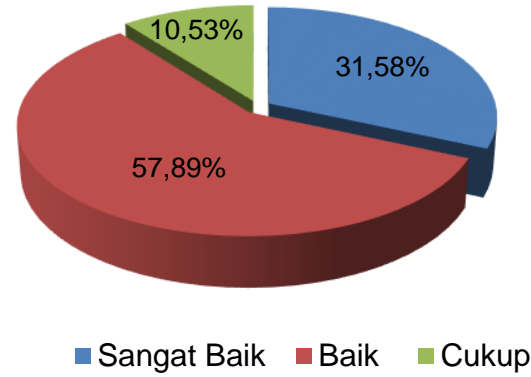

Gambar 1. Ketercapaian Aspek Sikap Siswa Siklus I

Gambar 1 menunjukkan bahwa capaian pada aspek sikap sudah dan telah mencapai target awal yaitu $75 \%$. Dalam hal ini, penilaian tidak dilanjutkan ke siklus II karena pencapaiannya sudah jauh di atas target, yaitu 89,47\%.

Hasil penilaian aspek kognitif siklus I disajikan pada Gambar 2. Hasil analisis siklus I terdapat 21 siswa yang telah tuntas dan 17 siswa yang tidak tuntas. Dari hasil analisis, terdapat tiga indikator kompetensi yang belum tercapai, yaitu mendeskripsikan reaksi reduksi dan oksidasi berdasarkan konsep perubahan biloks, menentukan oksidator, reduktor, hasil oksidasi, dan hasil reduksi dalam reaksi redoks, dan menjelaskan reaksi autoredoks. Ketercapaian pada indikator mendeskripsikan reaksi reduksi dan oksidasi berdasarkan konsep perubahan biloks sebesar $52,63 \%$. Pada indikator menentukan oksidator, reduktor, hasil oksidasi, dan hasil reduksi dalam reaksi redoks ketercapaiannya sebesar $59,21 \%$, dan pada indikator menjelaskan reaksi autoredoks sebesar $50 \%$.

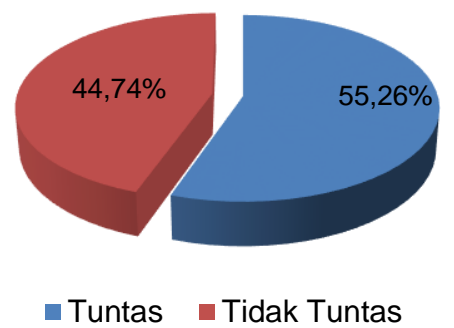

Gambar 2. Ketercapaian Aspek Kognitif Siswa Siklus I

Hasil penilaian aspek keterampilan disajikan pada Gambar 3.

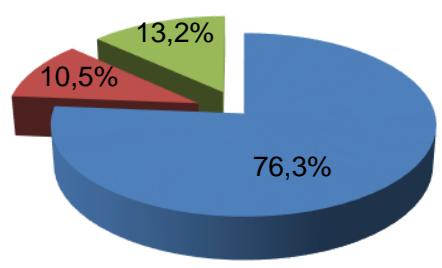

$$
\sim \mathrm{A} \sim \mathrm{A}-\square \mathrm{B}+
$$

Gambar 3. Ketercapaian Aspek Keterampilan Siswa Siklus I

Gambar 3 menunjukkan bahwa hasil pencapaian aspek kemandirian belajar dikategorikan menjadi tiga, yaitu A, A-, dan B+. Dalam hal ini dapat dilihat bahwa keterampilan siswa sudah tuntas $100 \%$ sehingga tidak perlu dilanjutkan ke siklus II.

Hasil penilaian aspek kemandirian belajar disajikan pada Gambar 4. Dari Gambar 4 dapat dilihat bahwa 31 siswa atau $81,58 \%$ telah tuntas aspek kemandirian belajar sedangkan 7 siswa atau $18,42 \%$ masih belum tuntas. Dalam hal ini, ketercapaian yang diperoleh telah mencapai target awal, yaitu $75 \%$, namun penilaian kemandirian belajar tetap dilanjutkan ke siklus II untuk melihat peningkatnnya. 


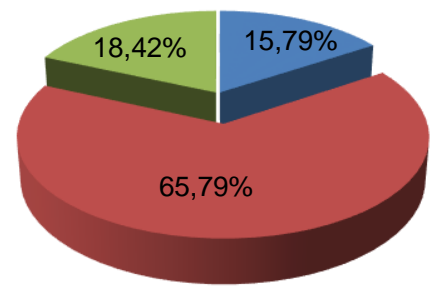

- Tinggi $\quad$ Sedang $\square$ Rendah

Gambar 4. Ketercapaian Aspek Kemandirian Belajar Siklus I

\section{d. Refleksi}

Dari hasil analisis penilaian, diperoleh bahwa masih terdapat aspek yang belum mencapai target, yaitu aspek kognitif. Oleh karena itu, dilakukan siklus II untuk mencapai target aspek kognitif, yaitu $67 \%$. Selain itu juga dilakukan penilaian pada aspek kemandirian untuk mengetahui peningkatan kemandirian belajar siswa.

\section{Siklus II}

\section{a. Perencanaan}

Pelaksanaan siklus II difokuskan pada perbaikan dari kendala-kendala siklus I. Materi yang diberikan pada siklus I difokuskan pada indikator-indikator yang belum tuntas. Kelompok belajar juga diubah dengan mempertimbangkan komposisi siswa yang lulus pada aspek kognitif siklus I dan pergantian asisten dengan siswa dengan nilai yang tertinggi pada siklus I.

\section{b. Pelaksanaan}

Siklus II ini dilaksanakan dalam 2 kali pertemuan, yaitu 1 kali pertemuan untuk penyampaian materi dan 1 kali pertemuan untuk evaluasi siklus II.

Pada pertemuan pertama, guru memberi pengarahan untuk memfokuskan pembelajaran pada indikator yang belum tercapai dan agar siswa lebih fokus dalam proses pembelajaran. Sub materi yang dibahas yaitu mendeskripsikan reaksi reduksi dan oksidasi berdasarkan konsep perubahan biloks, menentukan oksidator, reduktor, hasil oksidasi, dan hasil reduksi dalam reaksi redoks, dan menjelaskan reaksi autoredoks. Pembelajaran berlangsung seperti pada siklus I, yaitu penyampaian materi oleh guru dilanjutkan dengan latihan soal individual. Setelah itu, dilakukan diskusi kelompok kemudian presentasi. Guru lalu mengkonfirmasi hasil diskusi siswa dan menarik kesimpulan bersama dengan siswa, Guru lalu memberikan kuis kepada siswa dengan materi yang telah dipelajari.

Pada pertemuan kedua dilakukan evaluasi yaitu evaluasi aspek kognitif berupa tes dan pengisian angket kemandirian belajar.

\section{c. Pengamatan}

Hasil analisis penilaian aspek kognitif dapat dilihat pada Gambar 5.

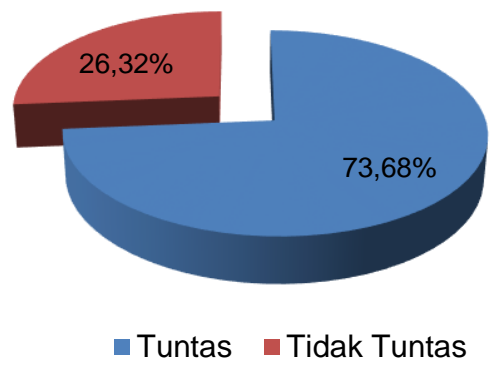

Gambar 5. Ketercapaian Aspek Kognitif Siklus II

Gambar 5 menunjukkan bahwa persentase ketuntasan siswa pada aspek kognitif siklus II adalah sebesar $73,68 \%$ dan persentase siswa yang tidak tuntas adalah $26,32 \%$. Capaian dari indikator kompetensi dari aspek kognitif juga sudah mencapai. Dari hasil tersebut, diketahui bahwa ketuntasan siswa telah mencapai target sehingga penilaian diakhiri di siklus II. .

Hasil analisi kemandirian belajar siswa dapat dilihat pada Gambar 6 . Gambar 6 menunjukkan capaian aspek kemandirian belajar sudah mencapai target dan sudah cukup baik karena persentase ketuntasan siswa adalah sebesar $89,47 \%$. Tiap indikator pada aspek kemandirian belajar juga sudah mencapai target awal yaitu $75 \%$. Dengan demikian, penilaian kemandirian belajar diakhiri di siklus II. 


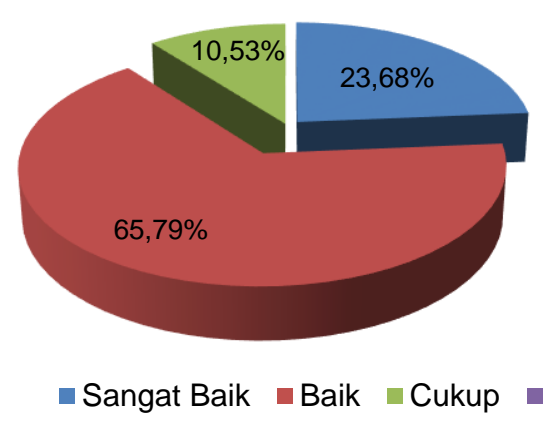

Gambar 6. Ketercapaian Aspek Kemandirian Belajar Siswa Siklus II

\section{d. Refleksi}

Berdasarkan hasil analisis data yang diperoleh pada siklus II, diketahui bahwa aspek kognitif dan kemandirian belajar yang dilakukan pada siklus II telah mencapai target sehingga penelitian ini diakhiri pada siklus II.

\section{Perbandingan Hasil 2 Siklus}

Berdasarkan data hasil penelitian siklus I dan siklus II, diketahui bahwa penerapan model pembalajaran kooperatif tipe TAI dapat meningkatkan kemandirian belajar dan prestasi belajar siswa pada materi redoks. Pada siklus I, aspek sikap dan aspekketerampilan siswa telah melebihi target awal yang ditentukan. Kemudian pada siklus II dilakukan penilaian lagi terhadap aspek kognitif dan aspek kemandirian belajar. Dari hasil yang diperoleh, terjadi peningkatan pada aspek kognitif dan kemandirian belajar di siklus II. Peningkatan ketercapaian aspek kognitif disajikan pada Gambar 7.

Berasarkan Gambar 7 dapat dilihat bahwa terjadi peningkatan persentase ketuntasan siswa dari siklus I ke siklus II hingga mencapai target awal yang telah ditentukan. Hal ini disebabkan karena pemanfaatan buku saku dengan lebih banyak dan pergantian kelompok dengan komposisi siswa yang lulus pada siklus I dibagi merata sehingga dapat memberi bimbingan pada teman sekelompoknya yang masih sulit memahami materi.

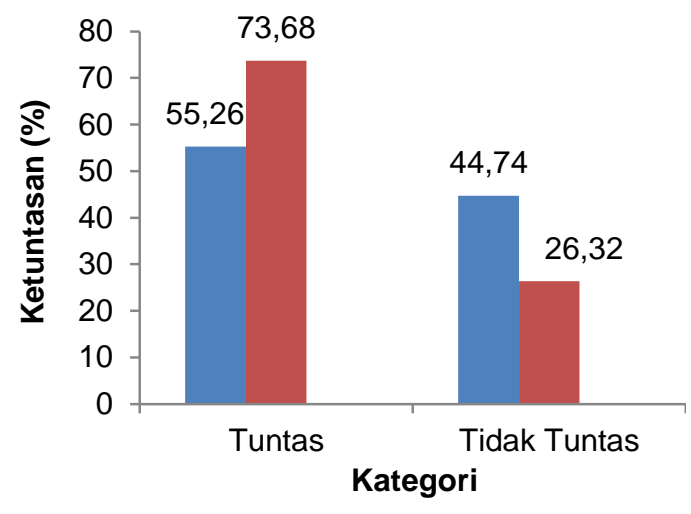

- Siklus I - Siklus II

Gambar 7. Diagram Perbandingan Aspek Kognitif Siklus I dan Siklus II

Peningkatan ketercapaian keman-
dirian belajar siswa pada aspek kemandirian belajar disajikan dalam Gambar 8. Pada siklus I, ketercapaian pada kategori sangat baik sebesar $15,79 \%$ dan meningkat menjadi $23,68 \%$ pada siklus II. Kategori Baik pada siklus I mencapai $65,79 \%$ dan meningkat menjadi $66,79 \%$ pada siklus II. Pada siklus I, ketercapaian kategori Cukup sebesar $18,42 \%$ dan menurun menjadi $10,53 \%$ pada siklus II. Peningkatan kemandirian belajar siswa terjadi karena siswa mulai terbiasa mengerjakan tugas individual pada pembelajaran. Selain itu, pembelajaran secara berkelompok dengan asisten teman sejawat juga membuat siswa menjadi lebih aktif dalam proses pembelajaran.

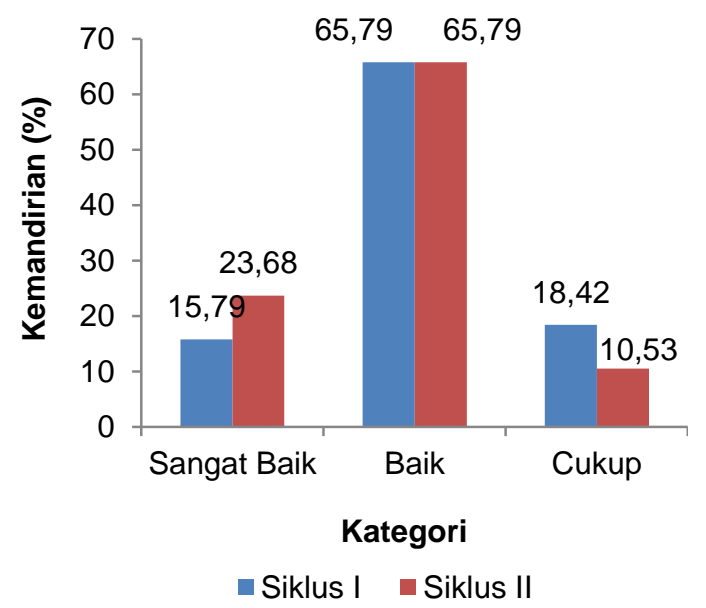

Gambar 8. Peningkatan Aspek Kemandirian Belajar Siklus dan Siklus II 
Model pembelajaran kooperatif tipe TAI berbantuan buku saku mendorong siswa untuk mandiri dalam proses pembelajaran meski berada di dalam kelompok. Proses pembelajaran yang dilakukan secara berkelompok dengan dipimpin oleh asisten teman sejawat membuat siswa tidak segan untuk aktif bertanya kepada asisten mengenai materi yang belum dipahami. Penggunaan media pembelajaan berupa buku saku membantu siswa untuk dapat memahami materi dan mengerjakan tugas-tugas kelompok maupun individu secara mandiri. Selain itu adanya reward untuk kelompok terbaik dari hasil kuis juga menjadi memotivasi siswa dalam proses pembelajaran.

Hasil penilaian dari siklus I dan perbaikan pada siklus II menunjukkan bahwa penelitian tindakan kelas ini telah berhasil karena semua aspek yang diukur telah mencapai target yang telah ditentukan. Peningkatan hasil dari siklus I ke siklus II disebabkan oleh: (1) penguatan materi pada indikator yang belum tuntas sehingga siswa dapat memahami materi dengan baik; (2) perubahan kelompok dan asisten kelompok yang didasarkan pada hasil evaluasi kognitif siklus I sehingga dalam tiap kelompok terdapat siswa selain asisten yang dapat membantu siswa yang belum memahami materi dengan baik; (3) pemanfaatan media belajar berupa buku saku yang lebih efisien.

Dari hasil penelitian yang telah diperoleh maka penelitian dengan menggunakan model pembelajaran kooperatif tipe TAl berbantuan buku saku berhasil karena telah mencapai target pada semua aspek yang diukur yaitu kemandirian belajar dan prestasi belajar yang terdiri dari kognitif, sikap, dan keterampilan.

\section{KESIMPULAN}

Berdasarkan hasil penelitian yang telah dilakukan, maka dapat disimpulkan bahwa penerapan model pembelajaran tipe TAl berbantuan buku saku pada materi redoks kelas X MIA 5 SMA Negeri 2 Boyolali dapat meningkatkan kemandirian belajar siswa dan prestasi belajar siswa. Persentase ketercapaian kemandirian belajar siswa pada siklus I sebesar $81,6 \%$ dan meningkat menjadi $89,5 \%$ pada siklus II. Persentase ketercapaian pada aspek sikap pada siklus I sebesar $89,5 \%$ dan aspek keterampilan sebesar $100 \%$. Persentase ketercapaian aspek kognitif mengalami peningkatan pada siklus I ke siklus II dari $55,3 \%$ menjadi $73,7 \%$.

\section{UCAPAN TERIMA KASIH}

Peneliti mengucapkan terima kasih kepada Kepala SMA Negeri 2 Boyolali , Drs. Makno, MH. atas izin yang diberikan kepada peneliti untuk melakukan penelitian, dan kepada guru kimia kelas X, Dra. Sri Rahayu, M.Pd. yang telah memberikan izin untuk menggunakan kelas X MIA 5 sebagai kelas penelitian.

\section{DAFTAR RUJUKAN}

[1] Taber, K. (2002). Chemical Misconception-Prevention, Diagnosis, and Cure. London: Royal Society of Chemistry.

[2] Slavin, R. E. (1995). Cooperative Learning: Theory, Research, and Practice (2nd ed.). Boston: Allyn \& Bacon.

[3] Gillies, R. M. (2008). The Effects of Cooperative Learning on Junior High School Students ' Behaviours , Discourse and Learning During a Science-Based Learning Activity, 29(3), 328-347. https://doi.org/10.1177/0143034308 093673

[4] Reda, T. (2015). International Journal of Science: Basic and Applied Research, 24(2), 33-44.

[5] Antoro, Y. D., Utomo, S. B., \& Masykuri, M. (2016).Jurnal Pendidikan Kimia , 5(3), 1-8.

[6] Ramandika, M. G. D., Susanti, E., \& Utami, B. (2013). Jurnal Pendidikan Kimia, 2(4), 41-50. 
[7] Noor, Z. A., Mulyani, S., \& Masykuri, M. (2015). Jurnal Pendidikan Kimia, 4(2), 130-136.

[8] Musfiqon, H. M. (2012). Media dan Sumber Pembelajaran. Jakarta: PT Prestasi Pustakarya.
[9] Retno, A. T. P., Saputro, S., \& Utami, B. (2015). Jurnal Pendidikan Kimia, 4(2), 74-81. 